\title{
CONFLITOS DE USO E OCUPAÇÃO DO SOLO EM ÁREAS DE PRESERVAÇÃO PERMANENTE NA MICROBACIA HIDROGRÁFICA DO CÓRREGO DO KARAMACY, ITAPEVA - SP
}

Nome do Autor (a) Principal

Amanda Aparecida de Lima

Nome (s) do Coautor (a) (s)

Yara Manfrin Garcia; Gabriela de Almeida Gil

Nome (s) do Orientador (a) (s)

Ronaldo Alberto Pollo

Instituição ou Empresa

Universidade Estadual Paulista "Julio de Mesquita Filho" - UNESP/FCA, Botucatu

E-mail de contato: aalima2603@gmail.com

Palavras-chave: Sistemas de Informação Geográfica. Conflito de Uso e Ocupação do Solo. Áreas de Preservação Permanente.

\section{INTRODUÇÃO}

Segundo Garcia (2011) as Áreas de Preservação Permanente (APPs) devem ter a vegetação mantida sem qualquer tipo de alteração, com o objetivo de preservação dos recursos hídricos, estabilidade geológica e da biodiversidade, sem deixar de lado a importância socioambiental. Em cima dessas afirmações realiza-se estudos que desenvolvem em seu conteúdo a preservação e a conservação das APPs conservando seus recursos hídricos.

Sendo assim, a referida Lei ํㅜ 12.651/12 com alterações feias pela Lei $n^{\circ}$ 12.272 de 17 de outubro de 2012 estabelece em seu artigo $2^{\circ}$ para a definição das APPs: 
Consideram-se de preservação permanente, pelo só efeito desta Lei, as florestas e demais formas de vegetação natural situadas:

a) ao longo dos rios ou de qualquer curso d'água desde o seu nível mais alto em faixa marginal cuja largura mínima será:

1 - de 30 (trinta) metros para os cursos d'água de menos de 10 (dez) metros de largura;

2 - de 50 (cinquenta) metros para os cursos d'água que tenham de 10 (dez) a 50 (cinquenta) metros de largura;

3 - de 100 (cem) metros para os cursos d'água que tenham de 50 (cinquenta) a 200 (duzentos) metros de largura;

4 - de 200 (duzentos) metros para os cursos d'água que tenham de 200 (duzentos) a 600 (seiscentos) metros de largura;

5 - de 500 (quinhentos) metros para os cursos d'água que tenham largura superior a 600 (seiscentos) metros;

b) ao redor das lagoas, lagos ou reservatórios d'água naturais ou artificiais;

c) nas nascentes, ainda que intermitentes e nos chamados "olhos d'água", qualquer que seja a sua situação topográfica, num raio mínimo de 50 (cinquenta) metros de largura (BRASIL, 2012).

De acordo com Borges et al. (2008), constatou-se que a identificação de campo hidromórfico, cerrado, cultura anual, mata, mineração, pastagem, pivô central, reflorestamento cortado, reflorestamento Eucaliptus e reflorestamento Pinus. Esses usos do solo podem ser identificados por meio da utilização de um software a fim de realizar a interpretação das imagens, e elaboração de um mapa de uso de solo e cobertura vegetal, quantificando a área de cada categoria.

Esses softwares estão inseridos numa ferramenta fundamental para se realizar tais estudos de análise ambiental é o SIG - Sistema de Informação Geográfica. O SIG é empregado a fim de unir dados de diferentes fontes como imagens de satélite e mapas digitais, além de outros materiais que informam dados ambientais analisando-os. Com isso cria-se um banco de dados georreferenciados (LIU, 2007).

\section{OBJETIVO GERAL}

O presente trabalho tem como objetivo identificar os diferentes tipos de uso e ocupação do solo em Áreas de Preservação Permanente na microbacia do córrego Karamacy, localizada em Itapeva (SP).os do solo dessas áreas que se encontram de forma inadequada. 


\section{Objetivos específicos}

Fazer uso da geotecnologia por meio do Sistema de Informação Geográfica e do Sensoriamento Remoto.

\section{METODOLOGIA}

A microbacia do Córrego do Karamacy localiza-se no município de Itapeva $\mathrm{SP}$, entre as coordenadas geográficas $48^{\circ} 53^{\prime} 44.12^{\prime \prime}$ a $48^{\circ} 50^{\prime} 58.24^{\prime \prime}$ de longitude

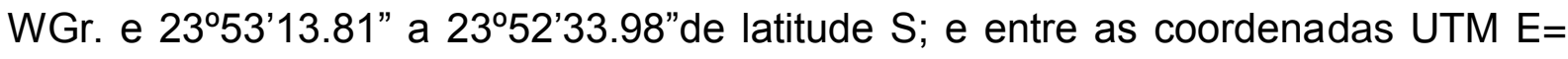
$7355000 \mathrm{~m}$ a $7362000 \mathrm{~m}$ e $\mathrm{N}=713000 \mathrm{~m}$ a $719000 \mathrm{~m}$.

A imagem de satélite utilizada foi do Landsat-08, sensor OLI (Operational Land Imager) e TIRS (Thermal Infrared Sensor), de novembro de 2013, órbita 221, ponto 77 , com resolução espacial de $30 \times 30$ metros, operando em sete bandas espectrais das quais, para este trabalho, utilizaram-se três bandas (6, 5 e 4), pois estas apresentam uma melhor visualização na discriminação dos alvos.

A primeira etapa, com a utilização de imagem de satélite, foi georreferenciar as bandas 6, 5 e 4, utilizando o módulo Reformat/ Resample do IDRISI. Como base, usou-se a carta planialtimétrica do IBGE, georreferenciada, no qual os pontos de controle para o georreferenciamento foram escolhidos em pontos homólogos.

Após o georreferenciamento, efetuou-se o recorte da imagem - extraindo assim apenas a área da bacia. Com as bandas das imagens georreferenciadas, foi realizado o processo de composição da imagem BGR (Blue, Green e Red). No Carta Linx, para a elaboração dos polígonos de uso e cobertura, criou-se uma tabela, no menu Tables/Add Fields e em cada polígono no comando polígono locator e feature properties colocou-se o número (código) correspondente a classe de uso.

Posteriormente, gerou-se as APPS com a criação de um raio de 50 metros circulando as áreas das nascentes e um buffer de 30 metros de cada lado da margem na drenagem ao longo do leito do córrego uma vez que a largura dos cursos d'água não ultrapassam os 10 metros.

Para a sobreposição dos usos e ocupação do solo com as APPs utilizou-se álgebra dos mapas executados no IDRISI. Após a sobreposição desses mapas, as 
áreas de ocorrência dos conflitos de acordo com as classes de uso foram devidamente quantificadas, executando as funções de cálculo de área.

\section{RESULTADOS}

Quanto aos usos e ocupações do solo, identificou-se oito classes, que são: fragmentos florestais, reflorestamento, represa, solo exposto, rodovia, eucalipto, mata ciliar e linha de transmissão de energia, popularmente conhecida como "Linhão".

Foram consideradas sob uso conflitante as áreas cultivadas e ocupadas com outros fins presentes nas APPs das nascentes e cursos d'água de acordo com as análises apresentadas na Figura 1.

Figura 1: Mapa de conflito de solo em APPs no córrego do Karamacy.

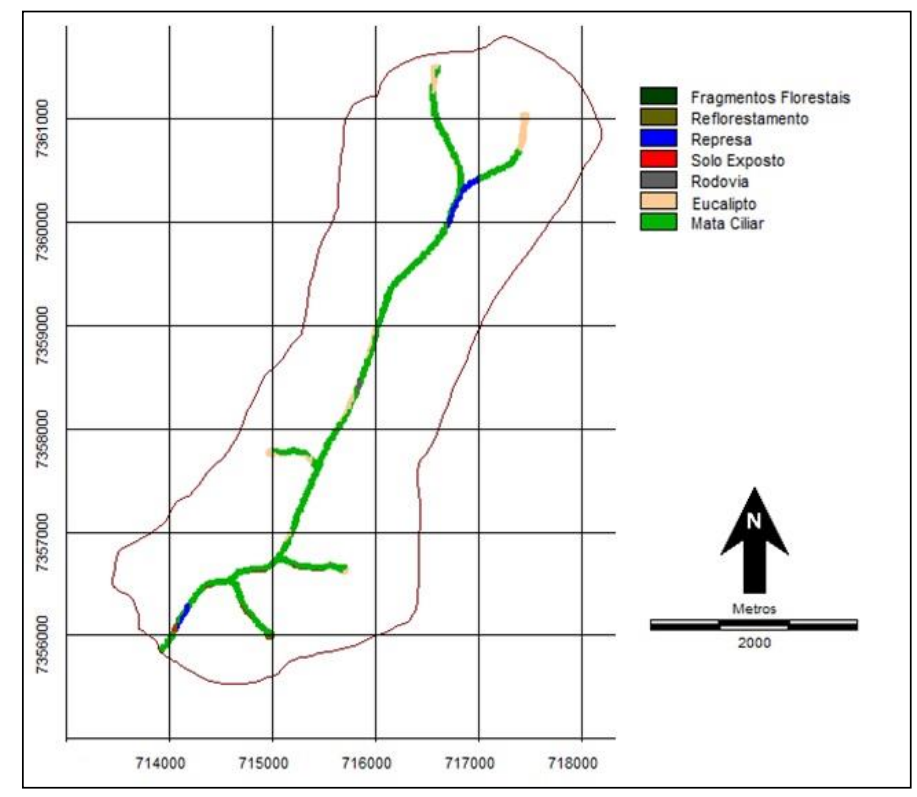

As classes de usos conflitantes foram as de eucalipto com uma área e porcentagem, respectivamente, de 8,61 ha (73,78\%); reflorestamento com 2,25ha $(19,28 \%)$; rodovia com 0,58 ha $(4,97 \%)$; e solo exposto com 0,23 ha (1,97\%). Já, as classes denominadas de represa e mata Ciliar, não entram como conflito. A Tabela 1 apresentada permite uma melhor interpretação e análise dos valores encontrados. 
Tabela 1: Distribuição das áreas e porcentagens dos conflitos de uso do solo do córrego do

\begin{tabular}{lcccc}
\multicolumn{4}{c}{ Karamacy } \\
\hline Classes de Uso de Terra & \multicolumn{2}{c}{ APPs } & \multicolumn{2}{c}{ Conflitos } \\
\hline \multirow{2}{*}{ Reflorestamento } & (ha) & $\%$ & (ha) & $\%$ \\
Represa & 2,25 & 3,39 & 2,25 & 19,28 \\
Solo Exposto & 3,97 & 5,97 & - & - \\
Rodovia & 0,23 & 0,35 & 0,23 & 1,97 \\
Eucalipto & 0,58 & 0,87 & 0,58 & 4,97 \\
Mata Ciliar & 8,61 & 12,96 & 8,61 & 73,78 \\
\hline Total & 50,81 & 76,46 & - & - \\
\hline
\end{tabular}

\section{CONCLUSÃO}

Quanto às áreas conflitantes encontradas na APP da microbacia de estudo a que teve maior significância foi o uso do solo indicado como Eucalipto com 73,78\% com 8,61ha de toda a área de conflito em relação à APP, portanto não estão de acordo com a Lei no $12.727 / 12$.

Em relação à visão de preservação e conservação do meio ambiente desenvolvidas no estudo, deve-se dar enfoque ao uso das geotecnologias Sistemas de Informação Geográfica e Sensoriamento Remoto que tornam possível a análise das áreas de conflito encontradas na microbacia do Karamacy com seus devidos mapeamentos. Sem se esquecer da utilização do Google Earth para melhor interpretação das imagens de satélite.

Essas informações trazem a possibilidade de novos estudos, que como este, geram benefícios para o meio ambiente.

\section{REFERÊNCIAS}

BRASIL. Lei n o 12.727, de 17 de outubro de 2012. Diário Oficial da União, Brasília, DF, 18 out. 2012. 2012. Disponível em: 
< http://www.planalto.gov.br/ccivil_03/_Ato2011-2014/2012/Lei/L12727.htm> Acesso em: 23 out. 2014.

BORGES, R. F.; BORGES, F. A.; COSTA, F. P. M.; AMA, L. N. Mapeamento do Uso do Solo e Cobertura Vegetal da Porção de Alto Curso da Bacia do Rio Uberabinha - MG. In: II Simpósio Brasileiro de Ciências Geodésicas e Tecnologias de Geoinformação. Recife, PE, 08 a 11 dez. 2008. Anais... Universidade Federal de Uberlândia - UFU, Instituto de Geografia - IG, Uberlândia, MG.

GARCIA, Y. M. Aplicação do Código Florestal como subsídio para p Planejamento Ambiental na Bacia Hidrográfica do Córrego do Palmitalzinho - Regente Feijó / São Paulo. Monografia UNESP, Presidente Prudente, SP, 142 p., 2011.

IBGE. Instituto Brasileiro de Geografia e Estatística. Carta topográfica: folha de Itapeva (SF-22-Z-DV-3). Serviço gráfico do IBGE, 1974. Escala 1:50.000. ITAPEVA. História e Perfil da Cidade. 2014. Disponível em:

<http://www.itapeva.sp.gov.br/conheca-itapeva/historia/>. Acesso em: 15 out. 2014.

LIU, W. T. H. Aplicações de sensoriamento remoto. Editora UNIDERP, Campo Grande, SP, 908p., 2007. 